9-1993

\title{
A Kalina Cycle Application for Power Generation
}

Mounir B. Ibrahim

Cleveland State University, m.ibrahim@csuohio.edu

Ronald M. Kovach

Cleveland Electric Illuminating Co.

Follow this and additional works at: https://engagedscholarship.csuohio.edu/enme_facpub

Part of the Mechanical Engineering Commons

How does access to this work benefit you? Let us know!

Publisher's Statement

NOTICE: this is the author's version of a work that was accepted for publication in Energy.

Changes resulting from the publishing process, such as peer review, editing, corrections, structural formatting, and other quality control mechanisms may not be reflected in this document. Changes may have been made to this work since it was submitted for publication. A definitive version was subsequently published in Energy, 18, 9, September 1993, 10.1016/ s0360-5442(06)80001-0

\section{Original Citation}

Ibrahim, M. B., and Kovach, R. M., 1993, "A Kalina Cycle Application for Power Generation," Energy, 18(9) pp. 961-969.

This Article is brought to you for free and open access by the Mechanical Engineering Department at EngagedScholarship@CSU. It has been accepted for inclusion in Mechanical Engineering Faculty Publications by an authorized administrator of EngagedScholarship@CSU. For more information, please contact library.es@csuohio.edu. 


\title{
A KALINA CYCLE APPLICATION FOR POWER GENERATION
}

\author{
Mounir B. Ibrahimt‡ and Ronalo M. Kovach\$ \\ - Mechanical Engineering Department, Cleveland State University, Cleveland, OH 44115 and \\ $\$$ Cleveland Electric lihminating Co., 33570 Lake Road, Avon Lake,
}

$\mathrm{OH} 44113$, U.S.A.

\begin{abstract}
A multi-component $\left(\mathrm{NH}_{3} / \mathrm{H}_{2} \mathrm{O}\right)$ Kalina-type cycle that utilizes the exhaust from a gas turbine is investigated in this paper. The turbine-inlet pressure of $5.96 \times 10^{6} \mathrm{~N} / \mathrm{m}^{2}$ and temperature of $755.372 \mathrm{~K}$ were kept constant, as well as the working fuid temperiture at the condenser outlet (at $290 \mathrm{~K}$ ). The $\mathrm{NH}_{3}$ mass fraction at the turbine inlet was varied along with the separator temperature and the effects on the cycle efficiency were studied. The relationships between turbine-inlet flow and the separator-inlet flow are shown in addition to the upper and lower $\mathrm{NH}_{3}$ mass-fraction bounds. The multi-component working-fluid cycle investigated is $10-20 \%$ more efficient than a Rankine cycle with the same boundary conditions.
\end{abstract}

\section{INTRODUCTION}

Since the first electric generating station in the U.S. (the Brush Electric Light Company in Philadelphia) went into service in 1881 , engineers have been working to improve the efficiency of the Rankine cycle for electricity production. ${ }^{1}$ The addition of superheat, multiple reheat and supercritical cycles have helped push the thermal efficiency from 7 to approximately $38 \%{ }^{2}$ The introduction and improvement of equipment such as air heaters, economizers and regenerative feedwater heaters have also contributed to the thermal efficiency increase. Advances in metallurgy, coupled with the previously mentioned cycle and equipment improvement, have raised the steam-gencrator outlet conditions from $1.0 \times 10^{6} \mathrm{~N} / \mathrm{m}^{2}$ and $500 \mathrm{~K}$ in the $1880 \mathrm{~s}$ to units which went on line in the late 1950s and early 1960s and operated at $2.4 \times 10^{7} \mathrm{~N} / \mathrm{m}^{2}$ and $865 \mathrm{~K}$. An example is the unit of the Cleveland Electric Company's Avon Lake Station Unit $\# 8 .^{3}$ However, one item has remained constant since Hero of Alexandriä's enigine: the use of water as the working fluid.

A method for increasing the thermal efficiency is the use of a binary cycle. In this system, the condenser of the higher boiling-cycle fluid is the boiler for the lower boiling-point fluid. As early as the 1920s, several binary cycles were being explored. Some of the fluids looked at were mercury, aluminum bromide, zinc ammonium chloride and diphenyloxide. ${ }^{4}$ Mercury/water binary cycles have been used most frequently. It should be noted that the New Hampshire Public Service Schiller plant went on line in the early 1950 s with a heat rate that is commendable by today's standard, $9700 \mathrm{~kJ} / \mathrm{kWh} .{ }^{5,6}$ It was decommissioned in the late $1970 \mathrm{~s}$. Metallurgical and safety concerns on the mercury portion curtailed further development. ${ }^{7} \mathrm{~A}$ similar cycle receiving recent attention is the Anderson power cycle, which has been patented. ${ }^{3.9}$ The Anderson cycle $\mathrm{H}_{2} \mathrm{O}$ condenser is the $\mathrm{R}-22$ refrigerant boiler. It is important to remember that, in these binary cycles, the two components are totally segregated.

The multi-component working-fluid power cycle studied in this paper is different from the previously mentioned binary cycles in that the working fluids progress through the cycle (compression, evaporation, expansion and condensation) together in the same flow stream. More than two fluids may be employed but this study is beyond the scope of this paper. This cycle has an advantage over traditional binary cycles by requiring one less boiler feed pump

* To whom all correspondence should be addressed. 


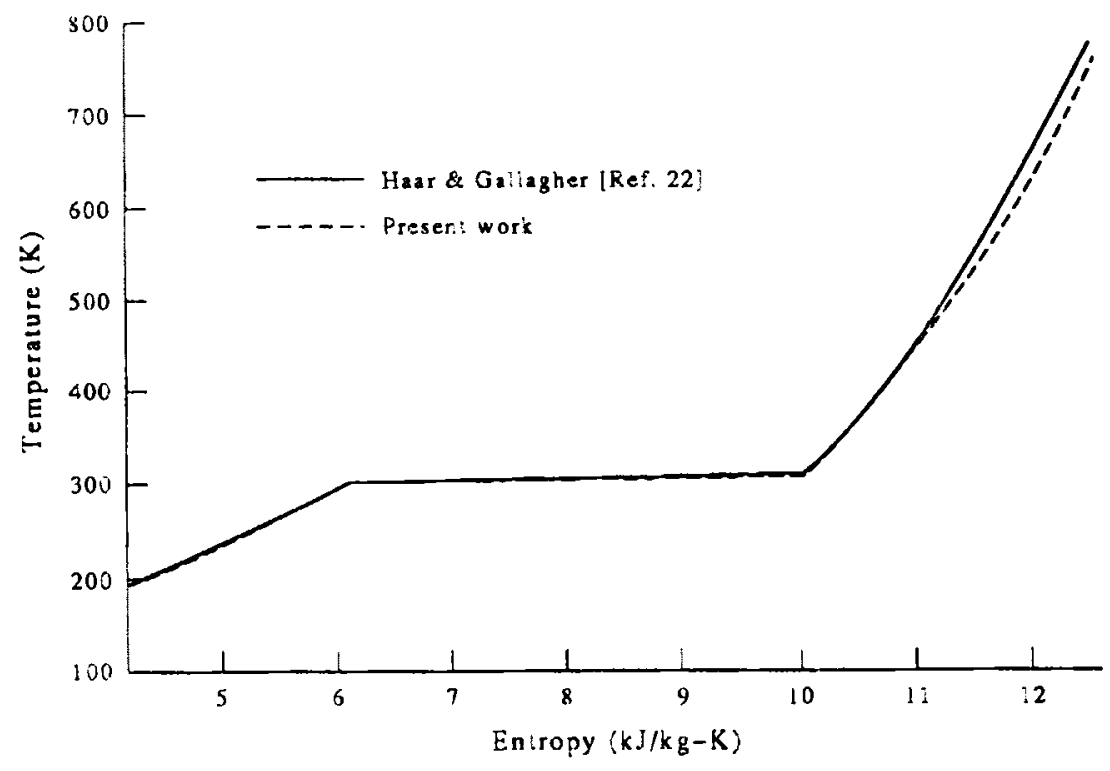

Fig. 1. $T-3$ diagram for pure $\mathrm{NH}_{3}$ for the present work and Ref. 23 ; pressure $=1.0 \times 10^{6} \mathrm{~N} / \mathrm{m}^{2}$.

and turbine. Research on this cycle has focused on $\mathrm{NH}_{3} / \mathrm{H}_{2} \mathrm{O}$ as the working-fluid pair. ${ }^{10-18}$ We will also examine a cycle with $\mathrm{NH}_{3} / \mathrm{H}_{2} \mathrm{O}$ as working fluid. Data for the $\mathrm{NH}_{3} / \mathrm{H}_{2} \mathrm{O}$ mixture above the $\mathrm{NH}_{3}$ critical temperature are scarce. There are different ways of calculating properties above this temperature. One method is to interpolate between the saturation region (where experimental data are available) to a point on the vapor curve where the perfect mixture theory may be applied. ${ }^{19}$ Another method, used in this paper, is to calculate the pure component properties and multiply them by their respective mass fractions. ${ }^{20}$ Even with all of the research that has been done, unanswered questions remain. ${ }^{21}$

Agreement of thermodynamic properties used in this study with published literature data is good. Figure 1 shows a comparison of the entropy of pure $\mathrm{NH}_{3}$ at $1.0 \times 10^{6} \mathrm{~N} / \mathrm{m}^{2}$ for the

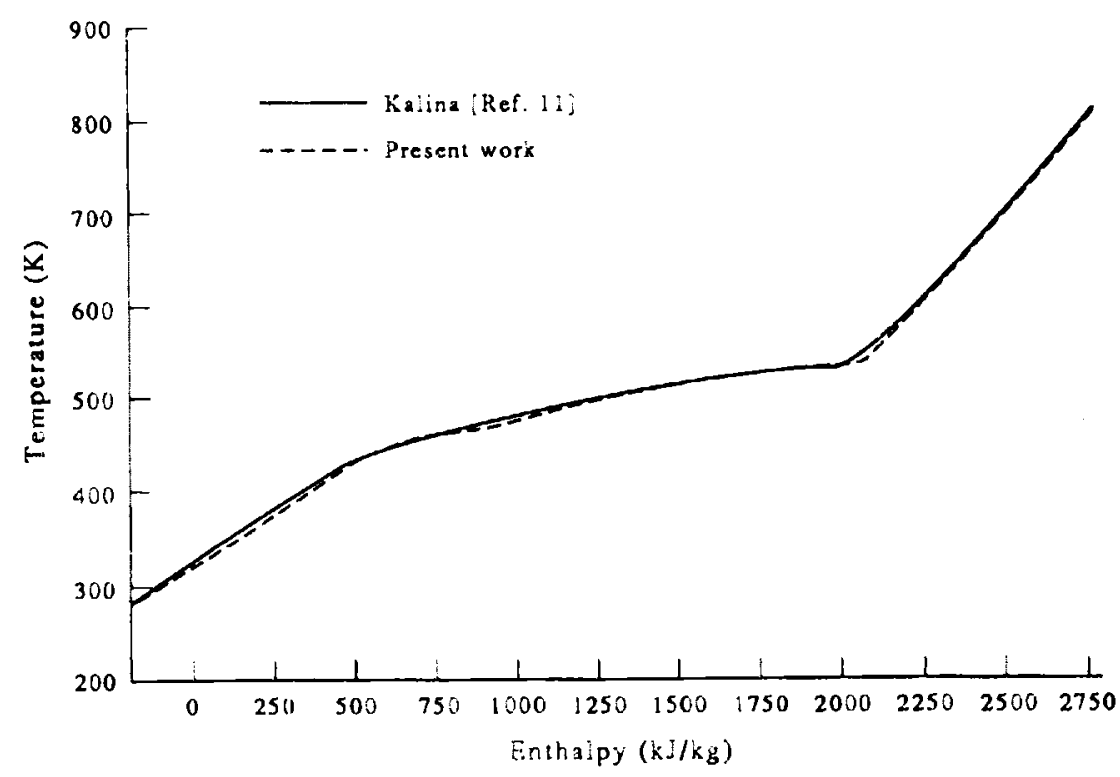

Fig. 2. $T-h$ diagram for an $\mathrm{NH}_{3} / \mathrm{H}_{2} \mathrm{O}$ mixture (5u\% by weight) for the present work and Ref. $11 ;$ pressure $=8.273 \times 10^{6} \mathrm{~N} / \mathrm{m}^{2}$. 


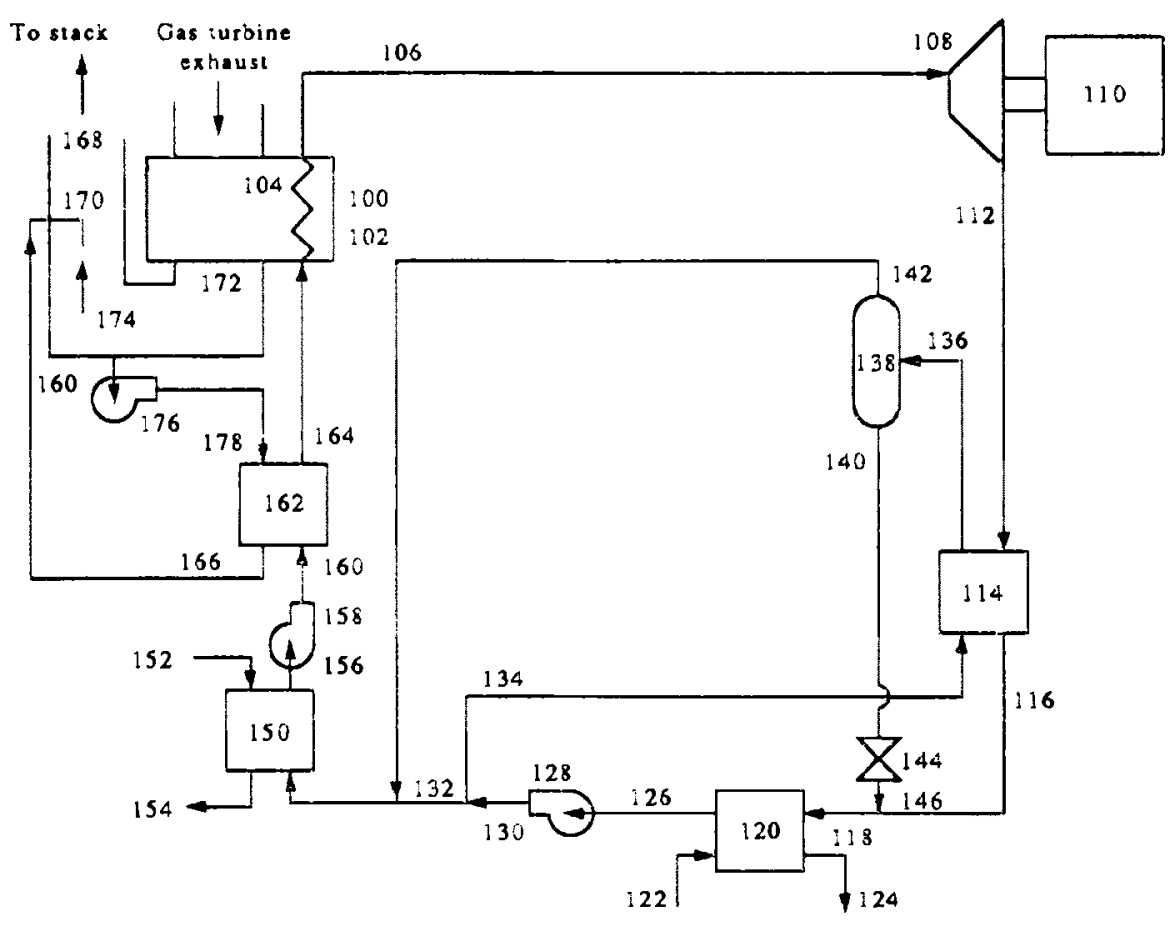

Fig. 3. Flow diagram for the multi-component cycle used in the present work.

present work with that calculated in Ref. 22. Our enthalpy and entropy values show agreement with published data over a pressure range from $1.0 \times 10^{6}$ to $1.0 \times 10^{7} \mathrm{~N} / \mathrm{m}^{2}$. Agreement for the $\mathrm{NH}_{3} / \mathrm{H}_{2} \mathrm{O}$ mixture is also good. Figure 2 is a comparison of temperature and enthalpy data for a mixture at $8.273 \times 10^{6} \mathrm{~N} / \mathrm{m}^{2} .{ }^{11}$ Equations used in calculating properties are reported in Ref. 23.

\section{CYCLE OPERATION}

Figure 3 shows the cycle used in this investigation, while Table 1 shows a list of the different components (with the number identifying it) used in the cycle. The cycle is similar to a simple

Table 1. Equipment list for the multi-component cycle used in the present work.

\begin{tabular}{cl}
\hline Number & \multicolumn{1}{c}{ Component } \\
\hline 100 & Boiler \\
102 & Heat Exchanger \\
104 & Boiler Tubes \\
106 & Turbine \\
110 & Generator \\
114 & Heat Exchanger \\
120 & Condenser \\
128 & Intermediate Pressure Pump \\
138 & Separator \\
144 & Throttle Valve \\
150 & Condenser \\
158 & Boiler Feed Pump \\
162 & Heat Exchanger \\
170 & Spray Head \\
174 & Gas Cooler/Cleaner \\
176 & Pump \\
\hline
\end{tabular}




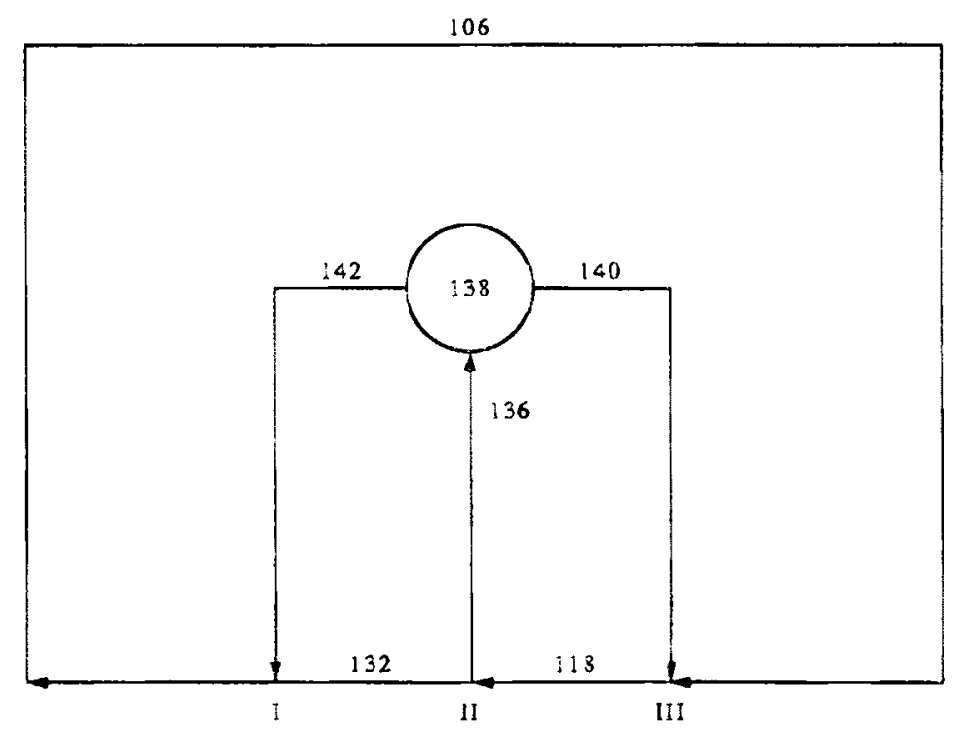

Fig. 4. Simplified flow diagram for the multi-component cycle used in the present work.

Rankine cycle with no reheat or regenerative feedwater heating but with one important addition that we are calling "the working fluid manipulating sub-circuit". Furthermore, an important feature of this cycle is that the working fiuid can be condensed above atmospheric pressure. Accordingly, the deaeration system, condenser vacuum and condenser priming pumps are eliminated; also, $\mathrm{O}_{2}$-related cycle problems are reduced. ${ }^{24}$

Figure 4 shows a simplified schematic diagram of "the working fluid manipulating sub-circuit" where the condensers and heat exchangers have been omitted. An $\mathrm{H}_{2} \mathrm{O}$ rich stream, state 146, is injected into line 118 before entering the condenser 120 . This process results in reducing the $\mathrm{NH}_{3}$ content and accordingly raising the bubble-point temperature of the working fluid. The net results are: (1) a liquid mixture (no vapor mixture) at the condenser outlet, line 126, (2) condenser pressure above one atmosphere.

It should be noted that the separator (138) operating pressure and temperature dictate the

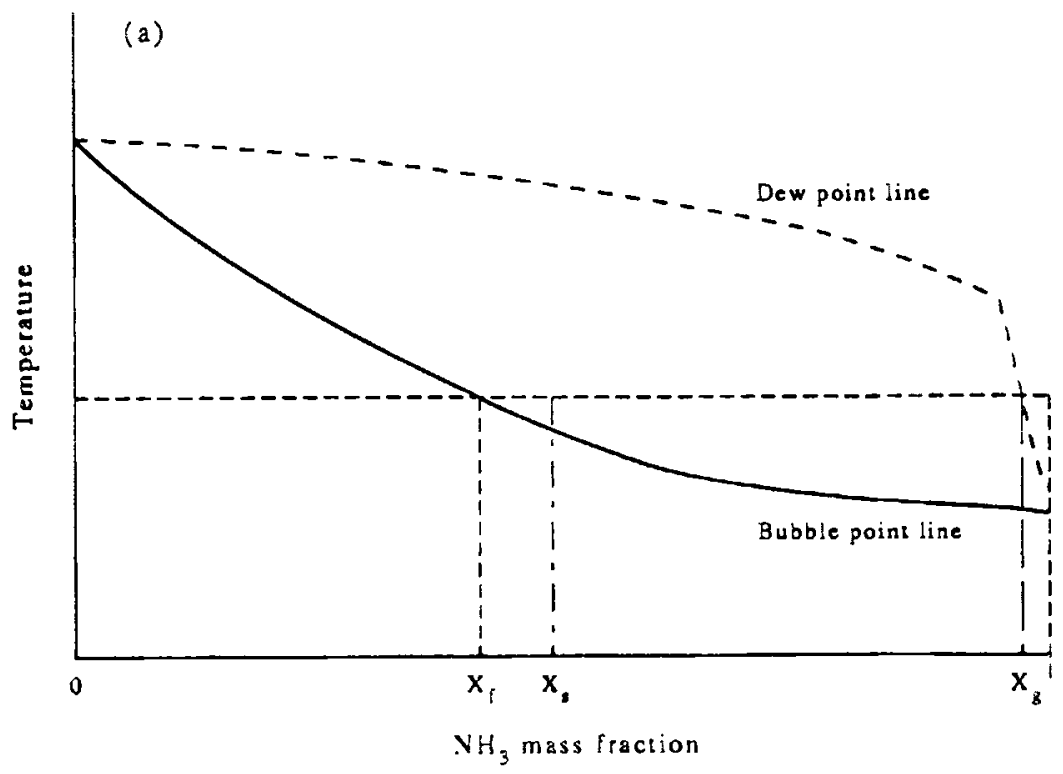

Fig. 5(a). Schematic phase diagram for the $\mathrm{NH}_{3} / \mathrm{H}_{2} \mathrm{O}$ mixture; pressure $=1.2 \times 10^{5} \mathrm{~N} / \mathrm{m}^{2}$. 
(b)

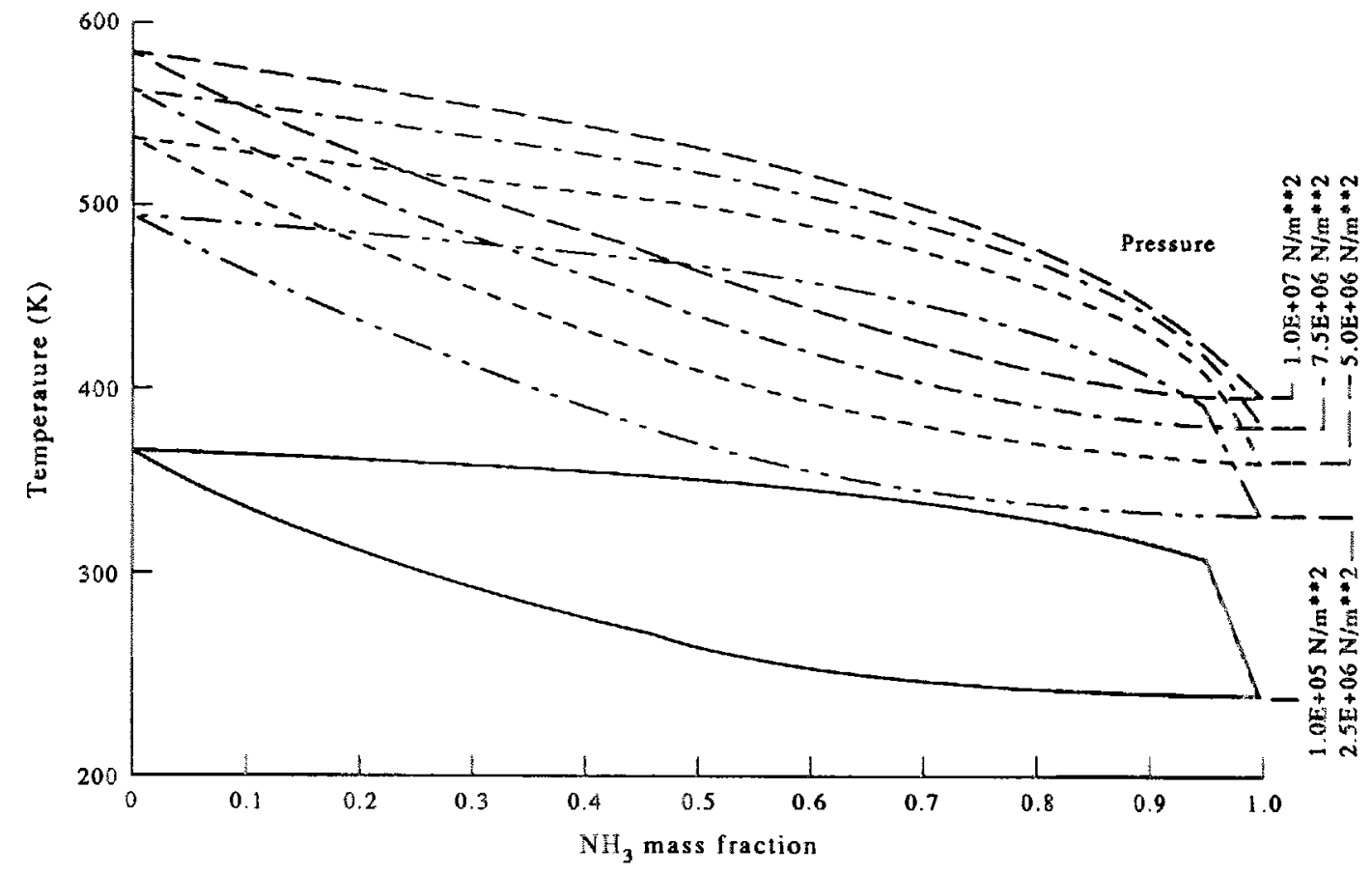

Fig. 5 (b). Two-phase curves for the $\mathrm{NH}_{3} / \mathrm{H}_{2} \mathrm{O}$ mixture; the pressure is varied from $1.0 \times 10^{5}$ to $1.0 \times 10^{7} \mathrm{~N} / \mathrm{m}^{2}$.

flow conditions at states 136,140 and 142 , and these, in turn, affect the condenser-outlet flow conditions. In order to illustrate this fact, Fig. 5(a) shows the two-phase diagram of an $\mathrm{NH}_{3} / \mathrm{H}_{2} \mathrm{O}$ mixture at pressure $1.2 \times 10^{5} \mathrm{~N} / \mathrm{m}^{2}$. The plot shows the temperature vs the $\mathrm{NH}_{3}$ mass fraction; below the solid line, we have a liquid mixture while the system is all in the vapor phase above the dotted line. At a particular separator temperature (shown as the horizontal dotted line), the inlet mixture (state 136 on Fig. 3) is at $X_{s}$, while the two exits from the separator (states 140 and 142 on Fig. 3) take place at $X_{\mathrm{f}}$ and $X_{\mathrm{g}}$, respectively. States 136,140 and 142 are determined via an iterative energy-balance procedure for the separator (see Ref. 23).

Figure 5(b) shows a farnily of two-phase curves for an $\mathrm{NH}_{3} / \mathrm{H}_{2} \mathrm{O}$ mixture for pressures from $1.0 \times 10^{5}$ to $1.0 \times 10^{7} \mathrm{~N} / \mathrm{m}^{2}$. It can be seen from the plots that the two-phase region is reduced in extent as the pressure is increased; this reduction, in turn, reduces the range of the temperature at which the separator will operate.

\section{RESULTS AND DISCUSSTON}

The separator-inlet flow (normalized with respect to the turbine-inlet flow) is plotted vs the separator temperature in Fig. 6 for $5.0 \times 10^{5} \mathrm{~N} / \mathrm{m}^{2}$. Holding the turbine-inlet mass fraction $X_{106}$ constant and raising the separator temperature reduces the amount of flow to the separator. Accordingly, less dilute flow is required. On the other hand, holding the separator temperature constant and increasing $X_{106}$ will increase the amount of flow to the separator.

Figure 7 shows the relationship between the separator temperature and separator-inlet $\mathrm{NH}_{3}$ mass fraction required for an energy balance around the separator at the pressure of $5.0 \times 10^{5} \mathrm{~N} / \mathrm{m}^{2}$. At other values for the separator pressure, another two-phase diagram is obtained and accordingly another relationship results between the separator temperature and separator inlet $\mathrm{NH}_{3}$ mass fraction. 


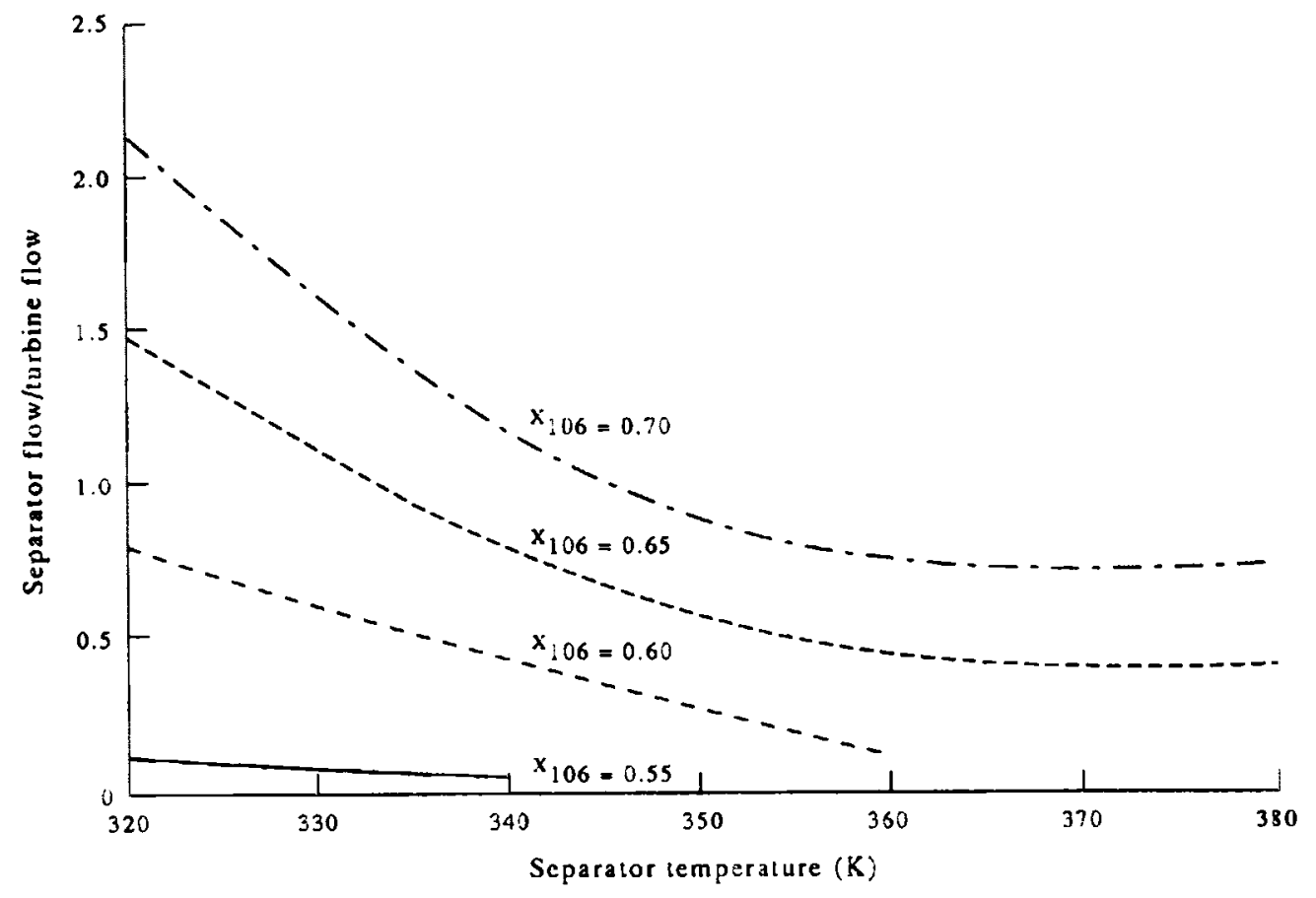

Fig. 6. Dimensionless separator flow rate vs separator temperature at different turbine-inlet $\mathrm{NH}_{3}$ mass fractions; pressure $=5.0 \times 10^{6} \mathrm{~N} / \mathrm{m}^{2}$.

Figure 8 shows the relation between cycle efficiency and separator temperature. For a given turbine-inlet mass fraction, $X_{106}$, as the separator temperature increases, the cycle efficiency increases up to a maximum and then starts to decrease. This behavior can be explained as follows: as the separator temperature is increased, the $\mathrm{NH}_{3}$ mass fraction at the separator inlet increases (see Fig. 7). In order to keep the bubble-point temperature constant, the condenser

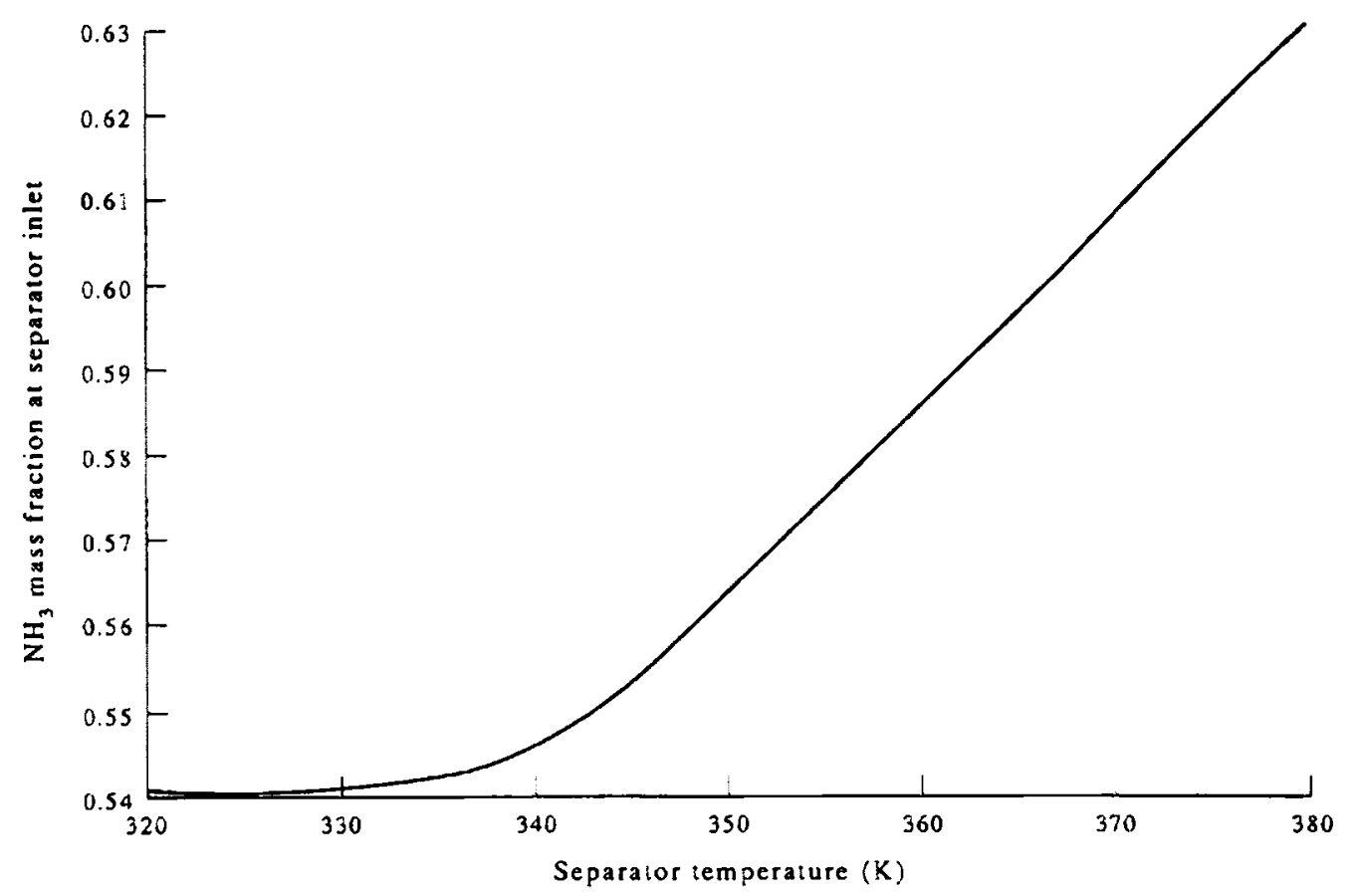

Fig. 7. The $\mathrm{NH}_{3}$ mass fractions at the separator inlet vs the separator temperature; pressure $=5.0 \times 10^{6} \mathrm{~N} / \mathrm{m}^{2}$. 


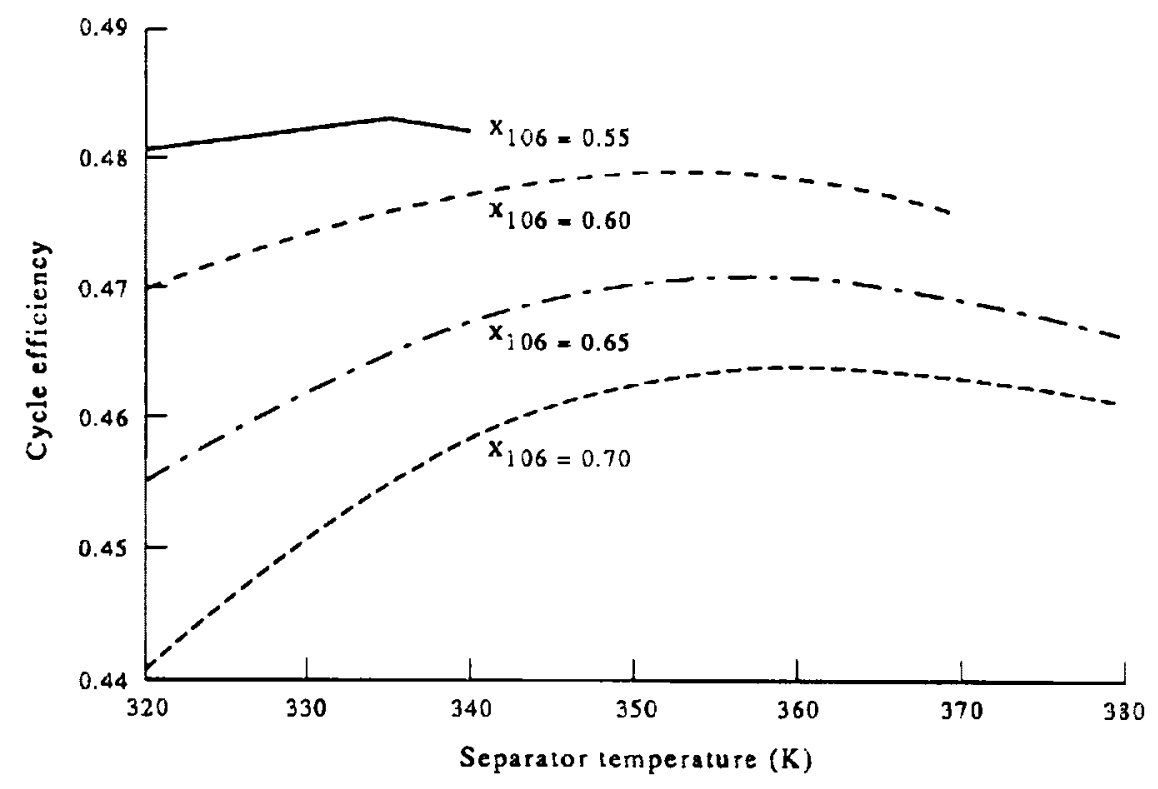

Fig. 8. Cyele thermal efficiency vs separator temperature at different turbine-inlet $\mathrm{NH}_{3}$ mass fractions; pressure $=5.0 \times 10^{6} \mathrm{~N} / \mathrm{m}^{2}$.

operating pressure must increase as the $\mathrm{NH}_{3}$ mass fraction in the condenser increases. This increase in the condenser pressure (turbine back pressure) results in decreases in both the turbine output and boiler heat addition. At a lower separator temperature, the reduction in the turbine output is less than that for heat addition; accordingly, the cycle efficiency increases. At a higher separator temperature, the opposite takes place. Also, as $X_{106}$ decreases at a given separator temperature, the cycle efficiency will increase. Since the separator-inlet flow and its operating temperature are closely related, Fig. 9 is basically another similar way to look at the cycle efficiency.

A similar study has been conducted to examine the effect of changing the separator operating pressure. When the cycle efficiency was plotted vs the separator temperature (not shown in the paper) for a turbine-inlet mass fraction $X_{106}=0.7$ and a fixed separator pressure, the trend was

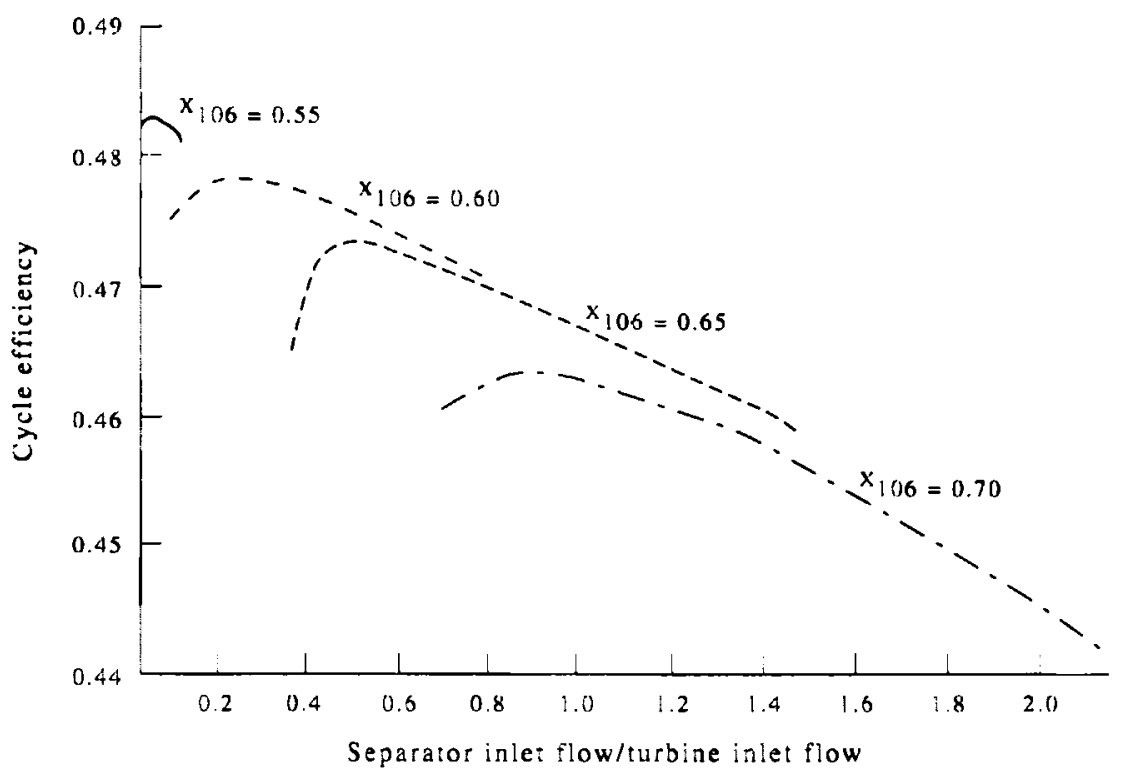

Fig. 9. Cycle thermal efficiency vs dimensionless separator flow rate at different turbine-inlet $\mathrm{NH}_{3}$ mass fractions; pressure $=5.0 \times 10^{6} \mathrm{~N} / \mathrm{m}^{2}$. 
similar to that shown in Fig. 8. Also, the plot showed that for a given separator temperature, the cycle efficiency will be increased by decreasing the separator pressure. For more details, see Ref. 23.

The Kalina cycle described in this paper has the following advantages over the Rankine cycle: (i) a 10-20\% more efficient vapor power cycle; (ii) reduced thermal pollution from the condenser circulating water; (iii) reduced combustion by-products such as $\mathrm{SO}_{2}$.

\section{CONCLUDING REMARKS}

In this paper, we have described the operation and design of a multi-component $\left(\mathrm{NH}_{3} / \mathrm{H}_{2} \mathrm{O}\right)$ Kalina-type cycle that utilizes the exhaust from a gas turbine.

For a given turbine-inlet mass fraction $X_{106}$, as the separator temperature increases, the cycle efficiency increases up to a maximum and then starts to decrease. Also, as $X_{106}$ decreases at a given separator temperature, the cycle efficiency will increase. On the other hand, for a given turbine-inlet mass fraction $X_{106}$ and separator temperature, the cycle efficiency will be increased by decreasing the separator pressure.

The Kalina cycle described in this paper is $10-20 \%$ more efficient than a Rankine cycle operating under similar conditions. Additional advantages were introduced with the cycle design by reducing thermal pollution from the circulating condenser water and reducing combustion by-products such as $\mathrm{SO}_{2}$.

The papers published on this cycle all show greater thermodynamic efficiencies than the Rankine cycle. ${ }^{11-18}$ The $3 \mathrm{MWe}$ Kalina cycle currently under construction in Canoga Park, California, should answer many questions as well as provide confirmation of the predictions made in papers such as Ref. 25.

Acknowledgements-The authors would like to express their thanks to Y. M. El-Sayed (Advanced Energy Systems), M. Tribus (Exergy Inc.) and C. H. Marston (Villanova University) for their very helpful comments and suggestions.

\section{REFERENCES}

1. Babcock and Wilcox, "Steam/its Generation and Use", 39th edn, Babcock and Wilcox, New York, NY (1978).

2. A. Bejan, Advanced Engineering Thermodynamics, Wiley, New York, NY.(1988).

3. R. L. Bannister and G. J. Silvestri Jr., "The Evolution of Central Station Turbine", Mech. Engng Mag., pp. 70-78 (February 1989).

4. G. A. Gaffert, Steam Power Station, McGraw-Hill, New York, NY (1946).

5. J. C. Westcott, personal communication (23 May 1990).

6. A. H. Zerban and E. P. Nye, Power Plants, International Textbooks, Scranton (1957).

7. S. G. Dukelow, personal communication (31 August 1988).

8. J. H. Anderson, Pollution Engng 21, 94 (1989).

9. U.S. Patent, No. 4,660,511 (1987).

10. Y. M. El-Sayed and M. Tribus, "Thermodynamic Properties of Water-Ammonia Mixture Theoretical Implementation for Use in Power Cycle Analysis", Center for Advảnced Engineering Study, Massachusetts Institute of Technology, Cambridge, MA (1985).

11. A. 1. Kalina, Trans. ASME J. Engng Gas Turbine Power 106, 737 (1984).

12. C. H. Marston, Trans. ASME J. Engng Gas Turbine Power 112, 107 (1990).

13. C. H. Marston, "A Family of Ammonia-Water Adjustable Proportion Fluid Mixture Cycles", Proc. of the 25th Intersociety Energy Conversion Engineering Conf., Vol. 2, pp. 160-165, Reno, NV (1990).

14. S. S. Stecco, "A Thermodynamics Analysis of the Kalina Cycles: Comparison, Problems and Perspective", ASME Paper 89-GT-149, The Int. Gas Turbine and Aeroengine Congress and Exposition, Toronto, Ontario, Canada (1989).

15. A. I. Kalina, M. Tribus, and Y. M. El-Sayed, "A Theoretical Approach to the Thermophysical Properties of Two-Miscible-Component Mixtures for the Purpose of Power-Cycle Analysis". ASME, Paper 86-WA/HT-54, ASME Winter Annual Meeting, Anaheim, CA (1986). 
16. U.S. Patent, No. 4,346,561 (1982).

17. Y. M. El-Sayed and M. Tribus, AES 1, 94 (1985).

18. A. I. Kalina and H. M. Leibowitz, "Applied Kalina Technology to a Bottoming Cycle for Ltility Combined Cycles", ASME Paper 87-GT-35, Anaheim, CA (1987).

19. M. Tribus, letter to the authors (27 February 1990).

20. K. H. Herold, letter to the authors (24 May 1990).

21. Y. M. El-Sayed, telephone interview (17 January 1990).

22. L. Haar and J. S. Gallagher, J. Phys. Chem. Ref. Data 7, 635 (1978).

23. R. M. Kovach, "Development of Multi-Component Working Fluid Vapor Power Cycle", M.S. Thesis, Cleveland State University, OH (1991).

24. A. Stodola, Steam and Gas Turbine, McGraw-Hill, New York, NY (1927).

25. M. Tribus, letter to the authors (8 February 1990).

\section{NOMENCLATURE}

$h=$ Enthalpy per unit mass $(\mathrm{kJ} / \mathrm{kg})$

$s=$ Entropy per unit mass $(\mathrm{kJ} / \mathrm{kg} \mathrm{K})$

$T=$ Temperature $(\mathrm{K})$

$X=$ Ammonia mass fraction
Subscript

$f=$ Saturated liquic

$g=$ Saturated vapor

$\mathrm{s}=$ State of the entering mixture

$x x x=A$ three-digit number identifies the

location used in Fig. 3 